\title{
Characterization of Antileishmanial Compounds from Lawsonia inermis L. Leaves Using Semi-High Resolution Antileishmanial Profiling Combined with HPLC-HRMS-SPE-NMR
}

\author{
Kashif Iqbal' ${ }^{\text {, Javeid lqbal }{ }^{1}, \text { Dan Staerk² and Kenneth T. Kongstad }}{ }^{2 *}$ \\ 1 Department of Pharmacology, Faculty of Pharmacy and Health Sciences, University of Balochistan, Quetta, Pakistan, \\ ${ }^{2}$ Department of Drug Design and Pharmacology, Faculty of Health and Medical Sciences, University of Copenhagen, \\ Copenhagen, Denmark
}

OPEN ACCESS

Edited by:

Marco Leonti,

University of Cagliari, Italy

Reviewed by:

Kannan R. R. Rengasamy, China Agricultural University, China Banasri Hazra

Jadavpur University, India

${ }^{*}$ Correspondence:

Kenneth T. Kongstad kenneth.kongstad@sund.ku.dk

Specialty section:

This article was submitted to

Ethnopharmacology,

a section of the journal

Frontiers in Pharmacology

Received: 21 December 2016

Accepted: 18 May 2017

Published: 31 May 2017

Citation:

lqbal K, lqbal J, Staerk D and Kongstad KT (2017) Characterization of Antileishmanial Compounds from

Lawsonia inermis L. Leaves Using Semi-High Resolution Antileishmanial

Profiling Combined with HPLC-HRMS-SPE-NMR.

Front. Pharmacol. 8:337. doi: 10.3389/fphar.2017.00337
This work describes an analytical platform based on semi-high-resolution antileishmanial profiling combined with hyphenation of high-performance liquid chromatography high-resolution mass spectrometry - solid-phase extraction - nuclear magnetic resonance spectroscopy, i.e., semiHR-antileishmanial assay/HPLC-HRMS-SPE-NMR. The platform enables fast pinpointing of HPLC peaks representing Leishmania tropica inhibitors in complex matrices, with subsequent structural identification of targeted inhibitors. Active analytes were cumulatively trapped on SPE cartridges and the structures elucidated by analysis of NMR spectra obtained in the HPLC-HRMSSPE-NMR mode. This led to the identification of six known compounds 2,4,6trihydroxyacetophenone-2-O- $\beta$-D-glucopyranoside (1), lalioside (2), luteolin-4'-O- $\beta$-Dglucopyranoside (3), apigenin-4'-O- $\beta$-D-glucopyranoside (4), luteolin (5), and apigenin (6). $\mathrm{IC}_{50}$ of the active compounds were determined with luteolin being the most potent inhibitor with an $\mathrm{IC}_{50}$ value of $4.15 \mu \mathrm{g} / \mathrm{ml}$. The platform proved to be an efficient method for the identification of $L$. tropica inhibitors.

Keywords: Leishmania tropica, Lawsonia inermis, leishmaniasis, semi-high-resolution inhibition profile, HPLCHRMS-SPE-NMR

\section{INTRODUCTION}

Leishmaniasis, caused by parasites belonging to the genus Leishmania (Family Trypanosomatidae), is a major public health problem in tropical and sub-tropical regions. The parasite is transmitted by the sand fly vector, with dogs, sheep, rats, horses, and cats being common animal hosts of leishmaniasis (Pearson and Sousa, 1996; Markle and Makboul, 2004). WHO has reported that people from 98 countries - covering five continents - are at high risk of contracting leishmaniasis, and it is estimated that approximately 12 million people are currently infected (Alvar et al., 2012). Cutaneous leishmaniasis is caused by different Leishmania species, e.g., Leishmania tropica, Leishmania major, Leishmania amazonensis, and Leishmania braziliensis. In Pakistan, L. tropica is the main cause of cutaneous leishmaniasis (Rowland et al., 1999; Brooker et al., 2004). First line therapy for cutaneous leishmaniasis in Europe, Asia, and Africa is pentavalent antimonials, i.e., sodium stibogluconate and meglumine antimoniate (Markle and Makboul, 2004). However, 
antimonials have severe side effects like myalgia, pancreatitis, cardiac arrhythmia, hepatitis, and accumulation of the drug in liver and spleen. Thus, there is an urgent need for new chemical entities for non-toxic and effective treatment of leishmaniasis (Brooker et al., 2004; Markle and Makboul, 2004).

Lawsonia inermis L. is commonly known as Henna or Mehndi (Family Lythraceae) (Kumar et al., 2005). It is native to Northern Africa and South-western Asia, and is cultivated in many tropical and sub-tropical regions (Cartwright-Jones, 2006). In Pakistan, it is widely found in the Dera Ismail khan and Bannu districts of the Khyber Pakhtunkhwa province. L. inermis is extensively used for different medicinal purposes, and possess a variety of biological and pharmacological activities, including antioxidant (Dasgupta et al., 2003), antibacterial (Ali et al., 2001), antifungal (Singh and Pandey, 1989), antiviral (Khan et al., 1991), antiparasitic (Okpeton et al., 2004), analgesic (Mohsin et al., 1989), cytotoxic (Ali and Grever, 1998), antidiabetic (Arayne et al., 2007), antileishmanial (Iqbal et al., 2016a,b) and protein glycation inhibitory activity (Sultana et al., 2009). L. inermis is chemically well investigated (Semwal et al., 2014), and more than 135 compounds have been reported from the genus. This includes phenolic compounds [flavonoids (Liou et al., 2013), naphthalenes (Hsouna et al., 2011), naphthoquinones (Almeida et al., 2012), coumarins (Chaudhary et al., 2010), alkylphenones (Hsouna et al., 2011)], terpenes [volatile terpenes (Hema et al., 2010), non-volatile terpenes (Liou et al., 2013)], aliphatic hydrocarbons, and alkaloids (Iqbal et al., 2016b).

A major bottleneck in our ongoing search for antiparasitic constituents from plants (Sairafianpour et al., 2002; Ziegler et al., 2002; Pedersen et al., 2009) has been the traditional time-consuming bioassay-guided isolation of the antileishmanial compounds. This urged us to implement new bioanalytical technologies for faster analyses targeting the bioactive constituents. Hyphenation of separation techniques, spectroscopic methods, and bioassays has in recent years proven to be an efficient strategy for this purpose (Van Beek et al., 2009). While the commonly used hyphenation of high-performance liquid chromatography coupled with high-resolution mass spectrometry (HPLC-HRMS) is a fast and sensitive technique, it has several limitations when it comes to full structural elucidation of complex natural products. Especially promising is therefore the additional hyphenation of HPLC and HPLC-HRMS with solid-phase extraction and nuclear magnetic resonance spectroscopy, i.e., HPLC-(HRMS)-SPE-NMR (Lambert et al., 2005; Johansen et al., 2011), which allows full structural identification of complex natural products directly from crude extracts. As HPLC-HRMS-SPE-NMR only allows for chemical analysis, the recent combination with semi-high-resolution and/or high-resolution bioactivity profiling, i.e., microfractionation in microplates followed by bioassaying to yield a semi-high or high-resolution inhibition profile, is one of the most promising technological developments within bioanalytical plant research. The resulting HR-bioassay/HPLC-HRMS-SPE-NMR technology platform has already proven effective for fast identification of $\alpha$-glucosidase inhibitors (Schmidt et al., 2012, 2014; Kongstad et al., 2015; Wubshet et al., 2015), aldose reductase inhibitors (Tahtah et al., 2015), $\alpha$-amylase inhibitors (Okutan et al., 2014), and radical scavengers (Wiese et al., 2013; Wubshet et al., 2013; Liu et al., 2015) directly from crude plant extracts. However, the current work is the first example of semi-highresolution antileishmanial inhibition profiling coupled with HPLC-HRMS-SPE-NMR.

\section{MATERIALS AND METHODS}

\section{Chemicals}

Fetal bovine serum (FBS), dimethyl sulfoxide (DMSO), RPMI1640 medium, Amphotericin B, penicillin, streptomycin, formic acid, analytical grade HPLC solvents (chloroform, methanol, ethyl acetate, $n$-hexane, acetone), and methanol- $d_{4}$ (99.8 atom $\%$ of deuterium) were purchased from Sigma-Aldrich (St. Louis, MO, United States), whereas silica gel $60 \quad 0.063-0.200 \mathrm{~mm}$ (70-230 mesh ASTM) was purchased from MERCK (Darmstadt, Germany). Water used for HPLC was purified by deionization and $0.22 \mu \mathrm{m}$ membrane filtration (Millipore, Billerica, MA, United States).

\section{Collection of Plant Material and Preparation of Crude Extract}

Leaves of Lawsonia inermis L. were collected from the territory of Dera Ismail Khan, Khyber Pakhtunkhwa (KPK), Pakistan in August and September 2014. Identification was performed by Dr. Siraj-ud-Din, Department of Botany, and a voucher specimen [accession number: Bot, 200101 (pup)] was deposited at Department of Botany, University of Peshawar (UOP), KPK. The leaves were washed with distilled water before drying in the shade at temperatures below $35^{\circ} \mathrm{C}$. The leaves were stored in a cool dark place until use. Ground material of L. inermis (leaves, $1 \mathrm{~kg}$ ) was extracted with methanol (2 L) for 1 week with regular stirring. The extract was filtered and concentrated in vacuo to afford $500 \mathrm{~g}$ of an oily extract.

\section{Preparative-Scale Fractionation}

The crude leaves extract (250 g) was fractionated by means of silica gel column chromatography $(100 \mathrm{~cm} \times 50 \mathrm{~mm}$ i.d column, silica gel $600.063-0.200 \mathrm{~mm}$ from MERCK (Darmstadt), Germany). A gradient elution was used starting with $n$-hexanechloroform (99:1) with $20 \%$ step-wise increments to $100 \%$ chloroform, followed by $20 \%$ increments of ethyl acetate, and subsequent $20 \%$ increments of methanol to $100 \%$ methanol. Each of the increments constituted $500 \mathrm{~mL}$ solvent, which yielded 89 fractions. Based on TLC, fractions 1-5 were pooled (fraction F1, 6 g), fractions 6-25 (F2, 9.5 g), fractions 26-40 (F3, $3.5 \mathrm{~g})$, fractions 41-45 (F4, $5 \mathrm{~g})$, fractions 46-65 (F5, $10 \mathrm{~g})$, fractions 66-80 (F6, 6 g), and fractions 81-89 (F7, 8.5 g). Fraction F1-F7 was subjected for in vitro antileishmanial activity, vide infra.

\section{In Vitro Antileishmanial Activity}

In vitro antileishmanial activity of $L$. inermis fractions were performed with clinically isolated L. tropica promastigotes 
(KWH23, Recently Pakistani clinically isolated strain, UOP, Pakistan). The in vitro antileishmanial growth inhibition assay was adopted from Iqbal et al. (2016b). Promastigotes of L. tropica were cultured in RPMI-1640 medium containing 10\% FBS, $200 \mathrm{U} / \mathrm{mL}$ of penicillin, and $0.2 \mathrm{mg} / \mathrm{mL}$ of streptomycin. The parasites were cultured at $26^{\circ} \mathrm{C}$ for 4 days in an incubator (Gallenkamp, Size 1, United Kingdom), where after promastigotes were harvested in sterile tubes. The number of promastigotes was measured by transferring $5-10 \mu \mathrm{L}$ to a haemocytometer (Reichert Technologies, Depew, NY, United States), and counting the number of promastigotes under upright microscope (CX31, Olympus, Tokyo, Japan). The viable cell count was calculated using the formula:

$$
\begin{aligned}
& \text { Viable cell count (live cells } / \mathrm{mL})= \\
& \frac{\text { Number of live cells counted }}{\text { Number of large corner squares counted }} \times \text { Dilution } \times 10,000
\end{aligned}
$$

The harvested promastigotes were subsequently centrifuge at $4^{\circ} \mathrm{C}$ at $2000 \mathrm{rpm}$ for $10 \mathrm{~min}$, the supernatant removed, and the pellet reconstituted in fresh RPMI-1640 medium with 10\% FBS to obtain a concentration of $1.4 \times 10^{6}$ promastigotes $/ \mathrm{mL}$ which was distributed in a 96 well culture plate $(180 \mu \mathrm{L}$ each $)$ and incubated for 2 days at $26^{\circ} \mathrm{C}$ with fractions of $L$. inermis.

The percentage inhibition of parasite growth was calculated as the mean of three replicate measurements with standard deviation using the equation:

Percentage inhibition $=$

count of control promastigotes - count of treated promastigotes $\times 100$ count of control promastigotes

$\mathrm{IC}_{50}$ values were determined by non-linear regression analysis using Graph Pad Prism 6 software.

\section{Preparative-Scale Fractionation of F5}

An injection solution of $0.1 \mathrm{~g} / \mathrm{mL}$ of fraction $\mathrm{F} 5$ was subjected to preparative-scale RP-HPLC using an Agilent 1100 system equipped with two preparative solvent delivery units, a multiple wavelength detector, an autosampler, and a fraction collector. Separation was performed using a $250 \mathrm{~mm} \times 21.2 \mathrm{~mm}$ i.d. Phenomenex Luna $\mathrm{C}_{18}$ column with $5 \mu \mathrm{m}$ particle size (Phenomenex, Torrance, CA, United States) operated at room temperature. The aqueous eluent (A) consisted of wateracetonitrile (95:5), and the organic eluent (B) consisted of wateracetonitrile $(5: 95)$ both acidified with $0.1 \%$ formic acid. The eluent flow rate was maintained at $20 \mathrm{~mL} / \mathrm{min}$. Repeated injection $(3 \times 900 \mu \mathrm{L})$ of the above solution was followed by a gradient elution profile as follows: $0 \mathrm{~min}, 10 \% \mathrm{~B} ; 40 \mathrm{~min}, 40 \% \mathrm{~B} ; 45 \mathrm{~min}$, $100 \% \mathrm{~B} ; 55 \mathrm{~min}, 100 \% \mathrm{~B} ; 56 \mathrm{~min}, 10 \% \mathrm{~B}$. This afforded $27.1 \mathrm{mg}$ of subfraction $1,10.9 \mathrm{mg}$ of subfraction $2,9.3 \mathrm{mg}$ of subfraction $3,8.3 \mathrm{mg}$ of subfraction $4,15.2 \mathrm{mg}$ of subfraction $5,10.0 \mathrm{mg}$ of subfraction $6,10.3 \mathrm{mg}$ of subfraction $7,6.8 \mathrm{mg}$ of subfraction $8,21.1 \mathrm{mg}$ of subfraction $9,5.3 \mathrm{mg}$ of subfraction $10,6.9 \mathrm{mg}$ of subfraction $11,5.3 \mathrm{mg}$ of subfraction $12,3.4 \mathrm{mg}$ of subfraction
$13,2.5 \mathrm{mg}$ of subfraction 14, $4.4 \mathrm{mg}$ of subfraction $15,96.6 \mathrm{mg}$ of subfraction $16,35.1 \mathrm{mg}$ of subfraction $17,3.9 \mathrm{mg}$ of subfraction $18,6.3 \mathrm{mg}$ of subfraction 19 , and $3.7 \mathrm{mg}$ of subfraction 20. All collected subfractions were concentrated under reduced pressure at $45^{\circ} \mathrm{C}$ in rotary evaporator. Initially, the subfractions were reconstituted in $0.1 \%$ DMSO in order to assess the $\mathrm{IC}_{50}$ values in the in vitro antileishmanial growth inhibition assay, vide supra.

\section{HPLC-HRMS-SPE-NMR}

The HPLC-HRMS-SPE-NMR system consisted of an Agilent 1200 chromatograph comprising of a quaternary pump, degasser, thermostated column compartment, auto sampler, and photodiode array detector (Santa Clara, CA, United States), a Bruker microOTOF-Q II mass spectrometer (Bruker Daltonik, Bremen, Germany) equipped with an electrospray ionization source and operated via a 1:99 flow splitter, a Knauer Smartline K120 pump for post-column dilution (Knauer, Berlin, Germany), a Spark Holland Prospekt2 SPE unit (Spark Holland, Emmen, Netherlands), a Gilson 215 liquid handler equipped with a $1 \mathrm{~mm}$ needle for automated filling of $1.7 \mathrm{~mm}$ NMR tubes, and a Bruker Avance III $600 \mathrm{MHz}$ NMR spectrometer $\left({ }^{1} \mathrm{H}\right.$ operating frequency $600.13 \mathrm{MHz}$ ) equipped with a Bruker Sample Jet sample changer and a cryogenically cooled gradient inverse triple-resonance $1.7 \mathrm{~mm}$ TCI probe-head (Bruker Biospin, Rheinstetten, Germany). Mass spectra were acquired in positive and negative ion modes, using drying temperature of $200^{\circ} \mathrm{C}$, capillary voltage of -4100 and $+4000 \mathrm{~V}$ for positive and negative ion modes, respectively, nebulizer pressure of 2.0 bar, and drying gas flow of $7 \mathrm{~L} / \mathrm{min}$. The negative ion mode HPLC-HRMS analysis was performed in a different experiment using identical chromatographic condition. A solution of sodium formate clusters was injected in the beginning of each run to enable internal mass calibration. Chromatographic separation was acquired on a Phenomenex Luna $\mathrm{C}_{18}(2)$ column (150 mm × $4.6 \mathrm{~mm}, 3 \mu \mathrm{m}, 100 \AA$ A; Phenomenex, Torrance, CA, United States) maintained at $40^{\circ} \mathrm{C}$, using water-acetonitrile (95:5) (eluent A) and acetonitrile-water (95:5) (eluent B), both acidified with $0.1 \%$ formic acid. At a flow rate of $0.5 \mathrm{~mL} / \mathrm{min}$ the following gradient elution profile was used: $0 \mathrm{~min}, 10 \% \mathrm{~B}$; $40 \mathrm{~min}, 40 \% \mathrm{~B} ; 45 \mathrm{~min}, 100 \% \mathrm{~B} ; 55 \mathrm{~min}, 100 \% \mathrm{~B} ; 56 \mathrm{~min}, 10 \%$ B. Cumulative SPE trapping of peaks 1-9 of L. inermis fraction F5 was performed after 10 consecutive separations. The HPLC eluate was diluted with Milli-Q water at a flow rate of $1.5 \mathrm{~mL} / \mathrm{min}$ prior to trapping on $10 \mathrm{~mm} \times 2 \mathrm{~mm}$ i.d. resin GP (general purpose, 5-15 $\mu \mathrm{m}$, spherical shape, polydivinyl-benzene phase) SPE cartridges from Spark Holland (Emmen, Netherlands), and analytes were trapped using absorption thresholds (280 and $330 \mathrm{~nm}$ ). SPE cartridges were conditioned with $1000 \mu \mathrm{L}$ of acetonitrile at $6 \mathrm{~mL} / \mathrm{min}$ and equilibrated with $500 \mu \mathrm{L}$ of Milli-Q water at $1 \mathrm{~mL} / \mathrm{min}$ prior to trapping. Loaded cartridges were dried with pressurized nitrogen gas for $45 \mathrm{~min}$ each prior to elution with methanol- $d_{4}$. Separations were controlled by Bruker HyStar version 3.2 software, automated filling of NMR tubes was controlled by Prep Gilson ST version 1.2 software, and automated NMR acquisition was controlled by Bruker IconNMR version 4.2 software. NMR data processing was performed using Bruker Topspin version 3.2 software. 


\section{NMR Experiments}

All NMR spectra were recorded in methanol- $d_{4}$ at $300 \mathrm{~K} .{ }^{1} \mathrm{H}$ and ${ }^{13} \mathrm{C}$ chemical shifts were referenced to the residual solvent signal ( $\delta 3.31$ and 49.00, respectively). One dimensional ${ }^{1} \mathrm{H}$ NMR spectra were with $30^{\circ}$ pulses, $3.66 \mathrm{~s}$ interpulse intervals, $64 \mathrm{k}$ data points, and multiplied with an exponential function corresponding to line-broadening of $0.3 \mathrm{~Hz}$ prior to Fourier transform. Phase-sensitive DQF-COSY spectra were recorded using a gradient-based pulse sequence with a 20 ppm spectral width and $2 \mathrm{k} \times 256$ data points (processed with forward linear prediction to $1 \mathrm{k}$ data points). Multiplicity-edited HSQC spectra were acquired with the following parameters: spectral width $20 \mathrm{ppm}$ for ${ }^{1} \mathrm{H}$ and $165 \mathrm{ppm}$ for ${ }^{13} \mathrm{C}, 2 \mathrm{k} \times 256$ data points (processed with forward linear prediction to $1 \mathrm{k}$ data points), and $2.0 \mathrm{~s}$ relaxation delay. $\mathrm{HMBC}$ spectra were optimized for ${ }^{n} J_{C, H}=10 \mathrm{~Hz}$ and acquired using the following parameters: spectral width $20 \mathrm{ppm}$ for ${ }^{1} \mathrm{H}$ and $222 \mathrm{ppm}$ for ${ }^{13} \mathrm{C}, 2 \mathrm{k} \times 128$ data points (processed with forward linear prediction to $1 \mathrm{k}$ data points), and $1.5 \mathrm{~s}$ relaxation delay.

\section{RESULTS}

The current work describes the use of HPLC-HRMS-SPENMR for dereplication of metabolites in extract of Lawsonia inermis leaves - in combination with semi-high-resolution antileishmanial profiling. Initially, crude methanol extract was tested for its ability to inhibit extracellular promastigotes of L. tropica at concentrations of $100,50,25$, and $10 \mathrm{mg} / \mathrm{ml}$, which resulted in $100 \%$ inhibition at all concentrations. The crude methanol extract was subsequently subjected to preparativescale column chromatography for separation into seven fractions (F1-F7). These fractions were tested for their ability to inhibit extracellular promastigotes, and as seen in Table 1, Fraction 5 showed the strongest antileishmanial activity.

Fraction 5 was selected for semi-high-resolution antileishmanial screening with the eluate from 10 to $40 \mathrm{~min}$ being separated into 20 sub-fractions in 96-well microplates. The eluate was evaporated, and the dried material in each well was redissolved in DMSO to make stock and working solutions. These solutions were assayed for their in vitro antileishmanial activity toward extracellular promastigotes. The active major constituents of subfractions 5, 7, 10, and 13 were identified by HPLC-HRMS-SPE-NMR directly from the crude extract and the $\mathrm{IC}_{50}$ values of the identified, active metabolites were determined.

\section{DISCUSSION}

\section{HPLC-HRMS-SPE-NMR}

The major metabolites of the active fractions (peaks 2, 4, 5, 7, and 9), together with additional four peaks, were subjected to HPLCHRMS-SPE-NMR analysis (Figure 1). Detailed HRMS and NMR analysis resulted in identification of six known compounds 1-6 (Figure 2) corresponding to peaks 1, 2, 4, 5, 7, and 9, while for peaks 3,6 , and 8 , the quality of the NMR data did not allow
TABLE 1 | IC $\mathrm{C}_{50}$ values of Lawsonia inermis leaves extract and fractions.

\begin{tabular}{|c|c|c|}
\hline Sample & Sample concentrations $(\mathrm{mg} / \mathrm{ml})$ & Percent inhibition \\
\hline \multirow[t]{4}{*}{ F1 } & 10 & $6.25 \pm 0.57$ \\
\hline & 25 & $18.75 \pm 1.00$ \\
\hline & 50 & $31.25 \pm 0.57$ \\
\hline & 100 & $37.5 \pm 0.57$ \\
\hline \multirow[t]{4}{*}{$\mathrm{F} 2$} & 10 & $7.50 \pm 0.00$ \\
\hline & 25 & $22.5 \pm 0.57$ \\
\hline & 50 & $30.0 \pm 1.00$ \\
\hline & 100 & $35.0 \pm 0.00$ \\
\hline \multirow[t]{4}{*}{ F3 } & 10 & $1.25 \pm 0.57$ \\
\hline & 25 & $6.25 \pm 0.00$ \\
\hline & 50 & $25.0 \pm 0.57$ \\
\hline & 100 & $27.5 \pm 0.57$ \\
\hline \multirow[t]{4}{*}{$\mathrm{F} 4$} & 10 & $6.25 \pm 0.57$ \\
\hline & 25 & $7.50 \pm 0.57$ \\
\hline & 50 & $12.5 \pm 0.57$ \\
\hline & 100 & $18.75 \pm 0.57$ \\
\hline \multirow[t]{4}{*}{ F5 } & 10 & $98.0 \pm 0.57$ \\
\hline & 25 & $98.0 \pm 0.57$ \\
\hline & 50 & $99.0 \pm 0.00$ \\
\hline & 100 & $100 \pm 0.00$ \\
\hline \multirow[t]{4}{*}{ F6 } & 10 & $12.5 \pm 0.57$ \\
\hline & 25 & $25.0 \pm 1.15$ \\
\hline & 50 & $37.5 \pm 0.57$ \\
\hline & 100 & $43.75 \pm 0.57$ \\
\hline \multirow[t]{4}{*}{$\mathrm{F} 7$} & 10 & $0.00 \pm 0.00$ \\
\hline & 25 & $12.5 \pm 0.57$ \\
\hline & 50 & $18.75 \pm 0.00$ \\
\hline & 100 & $25.0 \pm 0.57$ \\
\hline
\end{tabular}

Data represent mean percent inhibition $\pm S D$ of three replicates.

for full structure elucidation. ${ }^{1} \mathrm{H}$ NMR and HRMS data of 1-6 obtained in the HPLC-HRMS-SPE-NMR mode is provided in the compound summary paragraph.

The known compounds were identified by comparison of their spectral data with those reported in the literature as 2,4,6-trihydroxyacetophenone-2-O- $\beta$-D-glucopyranoside (1) (Lee et al., 1996), lalioside (2) (Takeda and Fatope, 1988), luteolin-4'-O- $\beta$-D-glucopyranoside (3) (Lee et al., 2002), apigenin $4^{\prime}$-O- $\beta$-D-glucopyranoside (4) (Ding et al., 2004), luteolin (5) (Scognamiglio et al., 2014), and apigenin (6) (Miyazawa and Hisama, 2003) and confirmed by 2D NMR analysis.

\section{Antileishmanial Activity}

In our work, F5 was subjected to prep HPLC for time slice based fractionation. It results in 20 sub-fractions which were further analyzed by extracellular promastigotes in which four sub-fractions showed promising inhibitory activity as shown in Table 2. After observation of their significant antileishmanial activity in the sub-fraction screening, lalioside (2), luteolin- $4^{\prime}$ $O-\beta$-D-glucopyranoside (3), apigenin $4^{\prime}-O-\beta$-D-glucopyranoside (4), luteolin (5), and apigenin (6) were isolated by preparativeand analytical-scale HPLC, and the materials were used for assessing $\mathrm{IC}_{50}$ values in antileishmanial activity assay. 


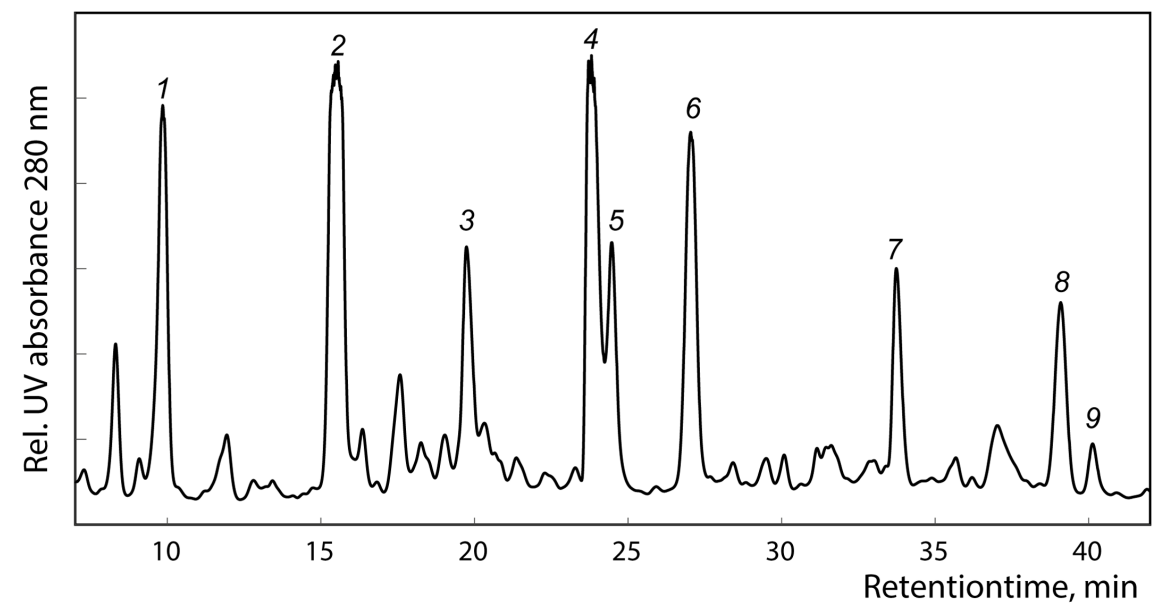

FIGURE 1 | HPLC chromatogram of Lawsonia inermis L. leaves F5 extract at $280 \mathrm{~nm}$ acquired in the HPLC-HRMS-SPE-NMR mode.<smiles>[R]c1c(O)cc(O)c(C(C)=O)c1O[C@H]1O[C@H](CO)[C@@H](O)[C@H](O)[C@H]1O</smiles><smiles>[R20]c1ccc(-c2cc(=O)c3c(O)cc(O)cc3o2)cc1[R]</smiles>

3: $\mathrm{R}_{1}=\mathrm{OH} ; \mathrm{R}_{2}=\mathrm{O}-\beta$-D-Glc

4: $\mathrm{R}_{1}=\mathrm{H} ; \mathrm{R}_{2}=\mathrm{O}-\beta-\mathrm{D}-\mathrm{GlC}$

5: $\mathrm{R}_{1}=\mathrm{OH} ; \mathrm{R}_{2}=\mathrm{H}$

6: $\mathrm{R}_{1}=\mathrm{H} ; \mathrm{R}_{2}=\mathrm{H}$

FIGURE 2 | Compounds identified from Lawsonia inermis L. leaves extract.

TABLE 2 | IC 50 values of major metabolites in active Lawsonia inermis $L$. subfractions.

\section{Compound (subfraction)}

Lalioside (SF 5)

Luteolin-4'-O- $\beta$-D-glucopyranoside (SF 7)

Apigenin-4'-O- $\beta$-D-glucopyranoside (SF 7)

Luteolin (SF 10)

Apigenin (SF 13)

Amphotericin B (Positive control)

Data represent mean $1 C_{50}$ values with $95 \%$ confidence intervals.

This is in agreement with previously observed inhibition of L. tropica by crude extract of different $L$. inermis plant parts (Iqbal et al., 2016b). Tasdemir et al. (2006) have previously investigated the structure-activity relationship of flavonoids, including luteolin (5) and apigenin (6). It was found that a minimum of two hydroxy substituents on the A ring, preferably on position 5,7 , and 8 , greatly increased the antileishmanial potential. Furthermore, the double bond between C-2 and C-3 proved to be important for the activity. Both luteolin (5) and apigenin (6) are di-substituted on the 'A' ring on positions 5 and 7 and both having the important double bond
$\Delta^{2,3}$ accounting for the $\mathrm{IC}_{50}$ values of 4.15 and $8.30 \mu \mathrm{g} / \mathrm{mL}$, respectively, with the differences in the antileishmanial potential attributes to the different substitution pattern on the $\mathrm{B}$ ring. Interestingly, the $4^{\prime}-O-\beta$-D-glucosides of 5 and 6 (10.27 and $9.51 \mu \mathrm{g} / \mathrm{mL}, 3$ and 4, respectively) showed a markedly decreased inhibitory effect against extracellular promastigotes. This is in line with previous reports that glucosylation on the A ring have similar effects (Tasdemir et al., 2006). Lalioside (2), a tetra-substituted acetophenone glucoside, showed promising inhibitory effects with an $\mathrm{IC}_{50}$ value of $5.02 \mu \mathrm{g} / \mathrm{mL}$ while the trisubstituted acetophenone glucoside (1) did not show noteworthy antileishmanial potential in the semi-high-resolution screening, indicating the importance of the C-3 hydroxyl substituent. While both luteolin (5) and apigenin (6) have previously been shown to possess activity against $L$. donovani $(0.8$ and $1.8 \mu \mathrm{g} / \mathrm{mL}$, respectively) (Tasdemir et al., 2006) this is the first report of their in vitro activity against $L$. tropica and the first time lalioside (2), luteolin- $4^{\prime}-O-\beta$-D-glucopyranoside (3), and apigenin- $4^{\prime}-O$ $\beta$-D-glucopyranoside (4) are reported against any Leishmania species.

\section{CONCLUSION}

In conclusion, luteolin and lalioside are potent inhibitors while apigenin, apigenin- $4^{\prime}-O-\beta$-D-glucopyranoside, and luteolin- $4^{\prime}$ $O-\beta$-D-glucopyranoside have moderate inhibitory effect on extracellular promastigotes of L. tropica. Further studies on identified compounds of Lawsonia Inermis are planned to investigate specificity and structure-activity relationship.

\section{AUTHOR CONTRIBUTIONS}

KI: Performed assay and chemical investigation. Participated in writing the manuscript. JI: Supervised and assisted KI on the antileishmanial work and participated in writing the manuscript. 
DS: Supervised and assisted KI on the chemical investigation and participated in writing the manuscript. KK: Took part in the chemical investigation and participated in writing the manuscript.

\section{ACKNOWLEDGMENTS}

HPLC equipment used for semi-high resolution bioassay profiles was obtained via a grant from The Carlsberg Foundation. The $600 \mathrm{MHz}$ HPLC-HRMS-SPE-NMR system used in this work was acquired through a grant from "Apotekerfonden af 1991", The Carlsberg Foundation, and the Danish Agency for Science, Technology and Innovation via the National Research Infrastructure funds. The research scholarship to $\mathrm{KI}$ is provided by the International Research Support Initiative Program by the Higher Education Commission of Pakistan. Laboratory technician Arife Önder is gratefully acknowledged for assistance in preparative isolation of pure compounds.

\section{2,4,6-Trihydroxyacetophenone-2-O- $\beta$-D-glucopyranoside}

(1): ${ }^{1} \mathrm{H}$ NMR $\left(\mathrm{CD}_{3} \mathrm{OD}, 600 \mathrm{MHz}\right) \delta 6.18(1 \mathrm{H}, \mathrm{d}, J=1.8 \mathrm{~Hz}$, $\mathrm{H}-3), 5.95(1 \mathrm{H}, \mathrm{t}, J=1.8 \mathrm{~Hz}, \mathrm{H}-5), 5.02\left(1 \mathrm{H}, \mathrm{d}, J=7.8 \mathrm{~Hz}, \mathrm{H}-1^{\prime}\right)$, 3.93, d, $J=12.1 \mathrm{~Hz}$ H-6 $\left.{ }^{\prime} \mathrm{A}\right), 3.73$ (dd, $\left.J=12.1,5.5 \mathrm{~Hz}, \mathrm{H}-6^{\prime} \mathrm{B}\right)$, $3.53\left(1 \mathrm{H}, \mathrm{dd}, J=9.2,7.8 \mathrm{~Hz}, \mathrm{H}-2^{\prime}\right), 3.48\left(2 \mathrm{H}, \mathrm{m}, \mathrm{H}-3^{\prime}, \mathrm{H}-5^{\prime}\right), 3.41$ $\left(1 \mathrm{H}, \mathrm{t}, J=9.5 \mathrm{~Hz}, \mathrm{H}-3^{\prime}\right), 2.69(3 \mathrm{H}, \mathrm{s}, \mathrm{Me}) ;(+)$ HRESIMS $m / z$ $331.1022[\mathrm{M}+\mathrm{H}]^{+}$(calcd for $\left.\mathrm{C}_{14} \mathrm{H}_{19} \mathrm{O}_{9}{ }^{+}, \Delta \mathrm{M} 0.4 \mathrm{ppm}\right)$.

Lalioside (2): ${ }^{1} \mathrm{H}$ NMR $\left(\mathrm{CD}_{3} \mathrm{OD}, 600 \mathrm{MHz}\right) \delta 5.90(1 \mathrm{H}, \mathrm{s}$, $\mathrm{H}-5), 4.53\left(1 \mathrm{H}, \mathrm{d}, J=7.8 \mathrm{~Hz}, \mathrm{H}_{-1}^{\prime}\right), 3.84$, dd, $J=12.1,2.3 \mathrm{~Hz}$,

\section{REFERENCES}

Ali, M., and Grever, M. R. (1998). A cytotoxic napthoquinone from Lawsonia inermis. Fitoterapia 69, 181-183.

Ali, N. A., Julich, W. D., Kusnick, C., and Lindequist, U. (2001). Screening of Yemeni medicinal plants for antibacterial and cytotoxic activities. J. Ethnopharmacol. 74, 173-179. doi: 10.1016/S0378-8741(00)00364-0

Almeida, P. J., Borrego, L., Pulido-Melian, E., and Gonzalez-Diaz, O. (2012). Quantification of p-phenylenediamine and 2-hydroxy-1,4-naphthoquinone in henna tattoos. Contact. Dermatitis 66, 33-37. doi: 10.1111/j.1600-0536.2011. 01992.x

Alvar, J., Velez, I. D., Bern, C., Herrero, M., Desjeux, P., Cano, J., et al. (2012). Leishmaniasis worldwide and global estimates of its incidence. PLoS ONE 7:e35671. doi: 10.1371/journal.pone.0035671

Arayne, M. S., Sultana, N., Mirza, A. Z., Zuberi, M. H., and Siddiqui, F. A. (2007). In vitro hypoglycemic activity of methanolic extract of some indigenous plants. Pak. J. Pharm. Sci. 20, 268-273.

Brooker, S., Mohammed, N., Adil, K., Agha, S., Reithinger, R., Rowland, M., et al. (2004). Leishmaniasis in refugee and local Pakistan populations. Emerg. Infect. Dis. 10, 1681-1684. doi: 10.3201/eid1009.040179

Cartwright-Jones, C. (2006). Developing Guidelineson Henna: A Geographical Approach. Masters' dissertation, Kent State University, Kent, $\mathrm{OH}$.

Chaudhary, G., Goyal, S., and Poonia, P. (2010). Lawsonia inermis Linnaeus: a phytopharmacological review. Int. J. Pharm. Sci. Drug. Res. 2, 91-98.

Dasgupta, T., Rao, A. R., and Yadava, P. K. (2003). Modulatory effect of henna leaf (Lawsonia inermis) on drug metabolizing phase I and Phase II enzymes, antioxidant enzymes, lipid peroxidation and chemically induced skin and forestomach papillomagenesis in mice. Mol. Cell. Biochem. 245, 11-22. doi: 10.1023/A:1022853007710

Ding, H. Y., Chan, Y. Y., Chang, W. L., and Lin, H. C. (2004). Flavonoids from the flowers of Pueraria lobata. J. Chin. Chem. Soc. 51, 1425-1428. doi: 10.1002/jccs. 200400210
H-6' A), 3.76 (dd, $\left.J=12.1,4.4 \mathrm{~Hz}, \mathrm{H}^{\prime} 6^{\prime} \mathrm{B}\right), 3.4-3.51$ (3H, m, H-3', $\left.\mathrm{H}-4^{\prime}, \mathrm{H}-5^{\prime}\right), 3.45$ (1H, m, H-2' $), 2.63$ (3H, s, Me); (+) HRESIMS $m / z 347.0976[\mathrm{M}+\mathrm{H}]^{+}$(calcd for $\mathrm{C}_{14} \mathrm{H}_{19} \mathrm{O}_{10}{ }^{+}, \Delta \mathrm{M}-0.8 \mathrm{ppm}$ ).

Luteolin-4'-O- $\boldsymbol{\beta}$-D-glucopyranoside (3): ${ }^{1} \mathrm{H}$ NMR $\left(\mathrm{CD}_{3} \mathrm{OD}\right.$, $600 \mathrm{MHz}) \delta 7.43\left(2 \mathrm{H}, \mathrm{m}, \mathrm{H}-2^{\prime}, \mathrm{H}-6^{\prime}\right), 7.30(1 \mathrm{H}, \mathrm{d}, J=8.3 \mathrm{~Hz}$, H-5') 6.59 (1H, s, H-3), 6.44 (1H, brs, H-8), 6.20 (1H, brs, H-6), $4.94\left(1 \mathrm{H}, \mathrm{d}, J=7.6 \mathrm{~Hz}, \mathrm{H}-1^{\prime \prime}\right), 3.93(1 \mathrm{H}, \mathrm{dd}, J=12.2,1.9 \mathrm{~Hz}, \mathrm{H}-$ $\left.6^{\prime \prime} \mathrm{A}\right), 3.74\left(1 \mathrm{H}, \mathrm{dd}, J=12.2,5.5 \mathrm{~Hz}, \mathrm{H}-6^{\prime \prime} \mathrm{B}\right), 3.54\left(1 \mathrm{H}, \mathrm{m}, \mathrm{H}-2^{\prime \prime}\right)$, $3.50\left(2 \mathrm{H}, \mathrm{m}, \mathrm{H}-3^{\prime \prime}, \mathrm{H}-5^{\prime \prime}\right), 3.43\left(1 \mathrm{H}, \mathrm{m}, \mathrm{H}-4^{\prime \prime}\right)$; (+) HRESIMS $m / z$ $449.1084[\mathrm{M}+\mathrm{H}]^{+}$(calcd for $\left.\mathrm{C}_{21} \mathrm{H}_{21} \mathrm{O}_{11}{ }^{+}, \Delta \mathrm{M}-1.3 \mathrm{ppm}\right)$.

Apigenin-4'-O- $\beta$-D-glucopyranoside (4): ${ }^{1} \mathrm{H}$ NMR $\left(\mathrm{CD}_{3} \mathrm{OD}\right.$, $600 \mathrm{MHz}) \delta 7.95\left(2 \mathrm{H}, \mathrm{d}, J=8.9 \mathrm{~Hz}, \mathrm{H}-2^{\prime} / \mathrm{H}^{-} 6^{\prime}\right), 7.25(2 \mathrm{H}, \mathrm{d}$, $\left.J=8.9 \mathrm{~Hz}, \mathrm{H}-3^{\prime} / \mathrm{H}^{-} 5^{\prime}\right), 6.66(1 \mathrm{H}, \mathrm{s}, \mathrm{H}-3), 6.48(1 \mathrm{H}, \mathrm{d}, J=2.1 \mathrm{~Hz}$, $\mathrm{H}-8), 6.26(1 \mathrm{H}, \mathrm{d}, J=2.1 \mathrm{~Hz}, \mathrm{H}-6), 5.04(1 \mathrm{H}, \mathrm{d}, J=7.6 \mathrm{~Hz}$,

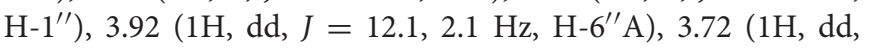
$\left.J=12.1,5.6 \mathrm{~Hz}, \mathrm{H}-6^{\prime \prime} \mathrm{B}\right), 3.50$ (3H, m, H-2 $\left.{ }^{\prime \prime}, \mathrm{H}-3^{\prime \prime}, \mathrm{H}-5^{\prime \prime}\right), 3.43$ $\left(1 \mathrm{H}, \mathrm{m}, \mathrm{H}-4^{\prime \prime}\right) ;(+)$ HRESIMS $m / z 433.1128[\mathrm{M}+\mathrm{H}]^{+}$(calcd for $\left.\mathrm{C}_{20} \mathrm{H}_{21} \mathrm{O}_{10}{ }^{+}, \Delta \mathrm{M} 0.2 \mathrm{ppm}\right)$.

Luteolin (5) : ${ }^{1} \mathrm{H}$ NMR $\left(\mathrm{CD}_{3} \mathrm{OD}, 600 \mathrm{MHz}\right) \delta 7.39(1 \mathrm{H}$, dd, $\left.J=8.6,2.3 \mathrm{~Hz}, \mathrm{H}-6^{\prime}\right), 7.38\left(1 \mathrm{H}, \mathrm{d}, J=2.3 \mathrm{~Hz}, \mathrm{H}-2^{\prime}\right), 6.90(1 \mathrm{H}$, $\left.\mathrm{d}, J=8.6 \mathrm{~Hz}, \mathrm{H}-5^{\prime}\right), 6.55(1 \mathrm{H}, \mathrm{s}, \mathrm{H}-3), 6.45(1 \mathrm{H}, \mathrm{d}, J=2.1 \mathrm{~Hz}$, H-8), $6.22(1 \mathrm{H}, \mathrm{d}, J=2.1 \mathrm{~Hz}, \mathrm{H}-6)$; (+) HRESIMS $m / z 287.0552$ $[\mathrm{M}+\mathrm{H}]^{+}\left(\right.$calcd for $\left.\mathrm{C}_{15} \mathrm{H}_{11} \mathrm{O}_{6}{ }^{+}, \Delta \mathrm{M}-0.8 \mathrm{ppm}\right)$.

Apigenin (6) : ${ }^{1} \mathrm{H}$ NMR $\left(\mathrm{CD}_{3} \mathrm{OD}, 600 \mathrm{MHz}\right) \delta 7.86(2 \mathrm{H}, \mathrm{d}$, $\left.J=8.9 \mathrm{~Hz}, \mathrm{H}-2^{\prime} / \mathrm{H}-6^{\prime}\right), 6.94\left(2 \mathrm{H}, \mathrm{d}, J=8.9 \mathrm{~Hz}, \mathrm{H}-3^{\prime} / \mathrm{H}-5^{\prime}\right)$, $6.60(1 \mathrm{H}, \mathrm{s}, \mathrm{H}-3), 6.47(1 \mathrm{H}, \mathrm{d}, J=2.1 \mathrm{~Hz}, \mathrm{H}-8), 6.22(1 \mathrm{H}, \mathrm{d}$, $J=2.1 \mathrm{~Hz}, \mathrm{H}-6) ;(+)$ HRESIMS $m / z 271.0606[\mathrm{M}+\mathrm{H}]^{+}$(calcd for $\left.\mathrm{C}_{15} \mathrm{H}_{11} \mathrm{O}_{5}{ }^{+}, \Delta \mathrm{M}-1.9 \mathrm{ppm}\right)$.

Hema, R., Kumaravel, S., Gomathi, S., and Sivasubramaniam, C. (2010). Gas chromatography-Mass spectroscopic analysis of Lasonia inermis leaves. Life Sci. J. 7, 48-50.

Hsouna, A. B., Trigui, M., Culioli, G., Blache, Y., and Jaoua, S. (2011). Antioxidants constituents from Lawsonia inermis leaves: Isolation, structure elucidation and antioxidative capacity. Food Chem. 125, 193-200. doi: 10.1016/j.foodchem. 2010.08 .060

Iqbal, K., Iqbal, J., and Afreen, M. S. (2016a). Comparative study on antileishmanial and cytotoxic activity of Lawsonia inermis bark and Aloe Vera leaves. Int. J. Biol. Pharm. Allied. Sci. 5, 1490-1500.

Iqbal, K., Iqbal, J., Umair, M., Farooq, U., Iqbal, M. M., Qamar, S., et al. (2016b). Anti-leishmanial and cytotoxic activities of extracts from three Pakistani Plants. Trop. J. Pharm. Res. 15, 2113-2119. doi: 10.4314/tjpr.v15i10.9

Johansen, K. T., Wubshet, S. G., Nyberg, N. T., and Jaroszewski, J. W. (2011). From retrospective assessment to prospective decisions in natural product isolation: HPLC-SPE-NMR analysis of Carthamus oxyacantha. J. Nat. Prod. 74, 2454-2461. doi: 10.1021/np200780m

Khan, M. M., Ali, A., Jain, D. C., Bhakuni, R. S., Zaim, M., and Thakur, R. S. (1991). Occurrence of some antiviral sterols in Artemisia annua. Plant Sci. 75, 161-165. doi: 10.1016/0168-9452(91)90230-6

Kongstad, K. T., Özdemir, C., Barzak, A., Wubshet, S. G., and Staerk, D. (2015). Combined use of high-resolution $\alpha$-glucosidase inhibition profiling and highperformance liquid chromatography-high-resolution mass spectrometry-solidphase extraction-nuclear magnetic resonance spectroscopy for investigation of antidiabetic principles in crude plant extracts. J. Agric. Food. Chem. 63, 2257-2263. doi: 10.1021/jf506297k

Kumar, S., Singh, Y. V., and Singh, M. (2005). Agro-History, Uses, Ecology and Distribution of Henna (Lawsonia inermis L. syn. Alba Lam). Henna: Cultivation, Improvement, and Trade. Jodhpur: Central Arid Zone Research Institute, $11-12$.

Lambert, M., Staerk, D., Hansen, S. H., and Jaroszewski, J. W. (2005). HPLC-SPENMR hyphenation in natural products research: optimization of analysis of 
Croton membranaceus extract. Magn. Reson. Chem. 43, 771-775. doi: 10.1002/ mrc. 1613

Lee, K. R., Hong, S. W., Kwak, J. H., Pyo, S. P., and Jee, O. P. (1996). Phenolic constituents from the Aerial parts of Artemisia stolonifera. Arch. Pharm. Res. 19, 231-234. doi: 10.1007/BF02976896

Lee, M. H., Son, Y. K., and Han, Y. N. (2002). Tissue factor inhibitory flavonoids from the fruits of Chaenomeles sinensis. Arch. Pharm. Res. 25, 842-850. doi: 10.1007/BF02977002

Liou, J. R., El-Shazly, M., Du, Y. C., Tseng, C. N., Hwang, T. L., Chuang, Y. L., et al. (2013). 1,5-Diphenylpent-3-en-1-ynes and methyl naphthalene carboxylates from Lawsonia inermis and their anti-inflammatory activity. Phytochemistry 88 , 67-73. doi: 10.1016/j.phytochem.2012.11.010

Liu, B., Kongstad, K. T., Qinglei, S., Nyberg, N. T., Jäger, A. K., and Staerk, D. (2015). Dual high-resolution $\alpha$-glucosidase and radical scavenging profiling combined with HPLC-HRMS-SPE-NMR for identification of minor and major constituents directly from the crude extract of Pueraria lobata. J. Nat. Prod. 78, 294-300. doi: 10.1021/np5009416

Markle, W. H., and Makboul, K. (2004). Cutaneous leishmaniasis recognition and treatment. Am. Fam. Physician 69, 455-460.

Miyazawa, M., and Hisama, M. (2003). Antimutagenic activity of flavonoids from Chrysanthemum morifolium. Biosci. Biotechnol. Biochem. 67, 2091-2099. doi: $10.1271 /$ bbb.67.2091

Mohsin, A., Shah, A. H., Al-Yahya, M. A., Tariq, M., Tanira, M. O., and Ageel, A. A. (1989). Analgesic, antipyretic activity and phytochemical screening of some plants used in traditional Arab system of medicine. Fitoterapia 60, 174-177.

Okpeton, T., Yolou, S., Gleye, C., Roblot, F., Loiseau, P., Bories, C., et al. (2004). Antiparasitic activities of medicinal plants used in ivory Coast. J. Ethnopharmacol. 90, 91-97. doi: 10.1016/j.jep.2003.09.029

Okutan, L., Kongstad, K. T., Jäger, A. K., and Staerk, D. (2014). High-resolution $\alpha$-amylase assay combined with high-performance liquid chromatographysolid-phase extraction-nuclear magnetic resonance spectroscopy for expedited identification of $\alpha$-amylase inhibitors: proof of concept and $\alpha$-amylase inhibitor in cinnamon. J. Agric. Food Chem. 62, 11465-11471. doi: 10.1021/jf5047283

Pearson, R. D., and Sousa, A. D. Q. (1996). Clinical spectrum of leishmaniasis. Clin. Infect. Dis. 22, 1-13. doi: 10.1093/clinids/22.1.1

Pedersen, M. M., Chukwujekwu, J. C., Lategan, C. A., Staden, J. V., Smith, P. J., and Staerk, D. (2009). Antimalarial sesquiterpene lactones from Distephanus angulifolius. Phytochemistry 70, 601-607. doi: 10.1016/j.phytochem.2009.02.005

Rowland, M., Munir, A., Durrani, N., Noyes, H., and Reyburn, H. (1999). An outbreak of cutaneous leishmaniasis in an Afghan refugee settlement in northwest Pakistan. Trans. R. Soc. Trop. Med. Hyg. 93, 133-136. doi: 10.1016/S00359203(99)90285-7

Sairafianpour, M., Kayser, O., Christensen, J., Asfa, M., Witt, M., Staerk, D., et al. (2002). Leishmanicidal and antiplasmodial activity of constituents of Smirnowia iranica. J. Nat. Prod. 65, 1754-1758. doi: 10.1021/np020244s

Schmidt, J. S., Lauridsen, M. B., Dragsted, L. O., Nielsen, J., and Staerk, D. (2012). Development of a bioassay-coupled HPLC-SPE-ttNMR platform for identification of $\alpha$-glucosidase inhibitors in apple peel (Malus $\times$ domestica Borkh.). Food Chem. 135, 1692-1699. doi: 10.1016/j.foodchem.2012.05.075

Schmidt, J. S., Nyberg, N. T., and Staerk, D. (2014). Assessment of constituents in Allium by multivariate data analysis, high-resolution $\alpha$-glucosidase inhibition assay and HPLC-SPE-NMR. Food. Chem. 161, 192-198. doi: 10.1016/j. foodchem.2014.03.062

Scognamiglio, M., Fiumano, V., Abrosca, B. D., Esposito, A., Choi, Y. H., Verpoortw, R., et al. (2014). Chemical interactions between plants in Mediterranean vegetation: the influence of selected plant extracts on Aegilops geniculata metabolome. Phytochemistry 106, 69-85. doi: 10.1016/j.phytochem. 2014.07.006
Semwal, R. B., Semwal, D. K., Combrinck, S., Cartwright-Jones, C., and Viljoen, A. (2014). Lawsonia inermis L. (Henna): Ethnobotanical, phytochemical and pharmacological aspects. J. Ethnopharmacol. 155, 80-103. doi: 10.1016/j.jep. 2014.05.042

Singh, V. K., and Pandey, D. K. (1989). Fungitoxic studies on bark extract of Lawsonia inermis against ringworm fungi. Hindustan Antibiot. Bull. 31, 32-35.

Sultana, N., Chaudhary, M. I., and Khan, A. J. (2009). Protein glycation inhibitory activities of Lawsonia inermis and its active principles. J. Enzym. Inhib. Med. Chem. 24, 257-261. doi: 10.1080/14756360802057500

Tahtah, Y., Kongstad, K. T., Wubshet, S. G., Nyberg, N. T., Jønsson, L. H., Jäger, A. K., et al. (2015). Triple aldose reductase/ $\alpha$-glucosidase/radical scavenging high-resolution profiling combined with high-performance liquid chromatography-high-resolution mass spectrometry-solid-phase extractionnuclear magnetic resonance spectroscopy for identification of antidiabetic constituents in crude extract of Radix Scutellariae. J. Chromatogr. A 1408, 125-132. doi: 10.1016/j.chroma.2015.07.010

Takeda, Y., and Fatope, M. O. (1988). New phenolic glucosides from Lawsonia inermis. J. Nat. Prod. 51, 725-729. doi: 10.1021/np50058a010

Tasdemir, D., Kaiser, M., Brun, R., Yardley, V., Schmidt, T. J., Tosun, F., et al. (2006). Antitrypanosomal and antileishmanial activities of flavonoids and their analogues: in vitro, in vivo, structure-activity relationship, and quantitative structure-activity relationship studies. Antimicrob. Agents Chemother. 50, 1352-1364. doi: 10.1128/AAC.50.4.1352-1364.2006

Van Beek, T., Tetala, K., Koleva, I., Dapkevicius, A., Exarchou, V., Jeurissen, S., et al. (2009). Recent developments in the rapid analysis of plants and tracking their bioactive constituents. Phytochemistry Rev. 8, 387-399. doi: 10.1007/s11101009-9125-9

Wiese, S., Wubshet, S. G., Nielsen, J., and Staerk, D. (2013). Coupling HPLC-SPENMR with a microplate-based high-resolution antioxidant assay for efficient analysis of antioxidants in food - Validation and proof-of-concept study with caper buds. Food Chem. 141, 4010-4018. doi: 10.1016/j.foodchem.2013.06.115

Wubshet, S. G., Moresco, H. H., Tahtah, Y., Brighente, I. M., and Staerk, D. (2015). High-resolution bioactivity profiling combined with HPLC-HRMSSPE-NMR: $\alpha$-Glucosidase inhibitors and acetylated ellagic acid rhamnosides from Myrcia palustris DC. (Myrtaceae). Phytochemistry 116, 246-252. doi: 10.1016/j.phytochem.2015.04.004

Wubshet, S. G., Schmidt, J. S., Wiese, S., and Staerk, D. (2013). Highresolution screening combined with HPLC-HRMS-SPE-NMR for identification of potential health-promoting constituents in sea aster and searocket-new Nordic food ingredients. J. Agric. Food Chem. 61, 8616-8623. doi: 10.1021/ jf402949y

Ziegler, H. L., Jensen, T. H., Christensen, J., Staerk, D., Hägerstrand, H., Sittie, A. A., et al. (2002). Possible artefacts in the in vitro determination of antimalarial activity of natural products that incorporate into lipid bilayer: apparent antiplasmodial activity of dehydroabietinol, a constituent of Hyptis suaveolens. Planta Med. 68, 547-549. doi: 10.1055/s-2002-32548

Conflict of Interest Statement: The authors declare that the research was conducted in the absence of any commercial or financial relationships that could be construed as a potential conflict of interest.

Copyright (c) 2017 Iqbal, Iqbal, Staerk and Kongstad. This is an open-access article distributed under the terms of the Creative Commons Attribution License (CC BY). The use, distribution or reproduction in other forums is permitted, provided the original author(s) or licensor are credited and that the original publication in this journal is cited, in accordance with accepted academic practice. No use, distribution or reproduction is permitted which does not comply with these terms. 